\title{
SEISMIC EVELUTION OF RC SPACE FRAME WITH RECTANGULAR AND EQUIVALENT SQUARE COLUMN BY PUSHOVER ANALYSIS
}

\author{
Ami A. Shah ${ }^{1}$, B. A. Shah ${ }^{2}$ \\ ${ }^{\text {I}}$ PG student, Applied Mechanics \& Structural Engineering Department, Faculty of Technology \& Engineering, The \\ M. S. University of Baroda, Vadodara, Gujarat, India \\ ${ }^{2}$ Associate Professor, Applied Mechanics \& Structural Engineering Department, Faculty of Technology \& \\ Engineering, The M. S. University of Baroda, Vadodara, Gujarat, India
}

\begin{abstract}
The present study is carried out to compare the seismic performance of RC frame structures of G+15 storey which consisting of rectangular shaped column as against equivalent square shaped column. The building is having $4.5 \mathrm{~m} x 4.5 \mathrm{~m}$ panels in both directions forming an overall plan dimension of $31.5 \mathrm{~m} \times 13.5 \mathrm{~m}$. All the beams are considered as $300 \mathrm{~mm} \times 600 \mathrm{~mm}$ in size and columns with of $3 \mathrm{~m}$ height in each floor. In the above model all the rectangular shaped columns are oriented with longer side in global $Y$ direction and shorter side parallel to global X direction. The M25 grade of concrete and Fe 415 grade of steel is considered for design. Pushover analysis is carried out, using commercially available software ETABS and behavior of RC frames is studied. One more factor which is studied in the current models is the material consumption variation for keeping the building in Immediate Occupancy stage. Also the comparison of normal RC frame and immediate occupancy level RC frame for both shaped columns is carried out. Quantity of concrete and quantity of steel is calculated for all the models and the overall structural cost is evaluated. Comparison for all the models in terms of quantity of materials and structural cost is also reported. It is concluded that the square cross section of columns perform better as compared to rectangular cross section of columns.
\end{abstract}

Keywords: Performance point, Pushover analysis, RC space frame

\section{INTRODUCTION}

Recent earthquake in which many concrete structures have been severely damaged or collapsed have indicated the need for evaluating the seismic adequacy of existing buildings. About $60 \%$ of land area of India is susceptible to damaging levels of seismic hazard. We can't avoid future earthquakes, but preparedness and safe building construction practices can certainly reduce the extent of damage and loss. To have a reliable estimate of a structures, sophisticated analysis tools are necessary. Nonlinear dynamic analysis is the most accurate method available for the analysis of structures subjected to earthquake excitation. Non-linear static (Pushover) analysis is also an attractive choice because of its simplicity and ability to identify component and systemlevel deformation demands with accuracy comparable to dynamic analysis. By conducting pushover analysis, we can predict the weak zones in the structures and then we will decide whether the particular part is required to be retrofitted or rehabilitated according to the requirement.

Conventional limit-state design is typically a two-level design approach having concern for the service-operational and ultimate-strength limit states for a building. Performance-based design can be viewed as a multi-level design approach that additionally has explicit concern for the performance of the building at intermediate limit states related to such issues as occupancy and life-safety standards. With the emergence of the performance based approach to design, there is a need to develop corresponding analysis tools. Nonlinear static (Pushover) analysis is often an attractive choice in this regard because of its simplicity and ability to identify component and system level deformation demands with accuracy comparable to dynamic analysis.

In the present work, a series of pushover analysis is carried out by using ETABS V9.7.4. Software. The analysis is carried out on the RC space frame for $\mathrm{G}+15$ storey buildings as per ATC-40 for the models having rectangular column and equivalent square columns with $31.5 \mathrm{~m}$ x $13.5 \mathrm{~m}$ overall plan of building. In both the models, optimization of column sizes are done on the basis of percentage of steel not exceeding 4 percentage, as per IS 456:2000. A comparison of the influence of the shape of the column on the seismic response of a building is presented here. The scope of the present study is limited to the analysis of buildings with rectangular columns oriented in one direction only.

\section{PUSHOVER ANALYSIS}

Pushover analysis is an analysis method in which the structure is subjected to monotonically increasing lateral force with an invariant height-wise distribution until a target displacement is reached. Pushover analysis consists of a series of sequential elastic analysis, superimposed to approximate a force-displacement curve of the overall structure. A two or three dimensional model which includes bilinear or trilinear load-deformation diagrams of all lateral force resisting elements are first created and gravity loads are applied initially. A predefined lateral load pattern which is distributed along the building height is then applied. The lateral forces are increased until some members yield. The 
IJRET: International Journal of Research in Engineering and Technold Rectangulass

structural model is modified to account for the reduced stiffness of yielded members and lateral forces are again increased until additional members yield. The process is continued until a control displacement at the top of building reaches a certain level of deformation or structure becomes unstable. The roof displacement is plotted against base shear to get the capacity curve.

\section{THE MATHEMATICAL MODELS} CONSIDERED

The problem is studied for a $31.5 \mathrm{~m} \times 13.5 \mathrm{~m}$ plan building with $4.5 \mathrm{~m} \times 4.5 \mathrm{~m}$ grid having rectangular columns and another model with equivalent square columns. All the rectangular columns are oriented such that longer side is parallel to the global $\mathrm{Y}$ direction and the shorter side is parallel to the global $X$ direction of the building. The height of the column in global $\mathrm{Z}$ direction is considered as $3 \mathrm{~m}$ for each floor level and the columns extend for $2.5 \mathrm{~m}$ below plinth level up to the foundation. The sizes of the columns are selected to satisfy codal provisions in both shapes and column sizes are as shown in Table-1. The slab is modelled as a shell element and a rigid diaphragm action is considered for the analysis. The columns are considered to be fixed at the foundation level. All the beams are considered rectangular in cross section of size $300 \mathrm{~mm}$ x $600 \mathrm{~mm}$ deep. The M25 grade of concrete and $\mathrm{Fe} 415$ grade steel reinforcement is considered. The building consist of 230 $\mathrm{mm}$ thick brick walls on outer periphery. Typical isometric and plan view of G+15 storey frame are as shown in Fig.1.

\section{LOADS CONSIDERED}

\begin{tabular}{|l|l|l|}
\hline Load Type & $\begin{array}{l}\text { Typical Floor } \\
\text { Level }\end{array}$ & $\begin{array}{l}\text { Terrace Floor } \\
\text { Level }\end{array}$ \\
\hline Dead Load & 4 kN/sq.m & 5 kN/sq.m \\
\hline Live Load & $2 \mathrm{kN} / \mathrm{sq} . \mathrm{m}$ & $1.5 \mathrm{kN} / \mathrm{sq} . \mathrm{m}$ \\
\hline
\end{tabular}

Wall Load on All Periphery Beams:-

\begin{tabular}{|l|l|l|}
\hline Load type & $\begin{array}{l}\text { Typical floor } \\
\text { (Wall Load) }\end{array}$ & $\begin{array}{l}\text { Terrace floor } \\
\text { (Parapet Wall } \\
\text { Load) }\end{array}$ \\
\hline Dead load & $11.63 \mathrm{kN} / \mathrm{m}$ & $5.10 \mathrm{kN} / \mathrm{m}$ \\
\hline
\end{tabular}

Table 1: Sizes of Rectangular Column and Equivalent Square Column

\begin{tabular}{|c|c|c|c|}
\hline $\begin{array}{l}\text { I Technn } \\
\text { Storey }\end{array}$ & $\begin{array}{l}\text { Rectangulars } \\
\text { Column }\end{array}$ & 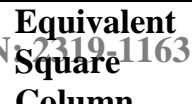 & pISSN: 2321-7308 \\
\hline No. & $\begin{array}{l}\text { Sections } \\
(\mathrm{mm})\end{array}$ & $\begin{array}{l}\text { Sections } \\
\text { (mm) }\end{array}$ & \\
\hline $\begin{array}{l}9 \text { To } \\
\text { Roof }\end{array}$ & $300 \times 500$ & 387 X 387 & C1 TO C32 \\
\hline 7,8 & $300 \times 650$ & $442 \times 442$ & C1 TO C 32 \\
\hline $4,5,6$ & $300 \times 750$ & $474 \times 474$ & $\mathrm{C} 1 \mathrm{TO} \mathrm{C} 32$ \\
\hline \multirow[b]{2}{*}{3} & $300 \times 900$ & $520 \times 520$ & $\begin{array}{l}\text { C6, C7, C10,C11, } \\
\text { C14 TO C16, C18, } \\
\text { C19, C22, C23, } \\
\text { C26, C27 }\end{array}$ \\
\hline & $300 \times 750$ & $474 \times 474$ & $\begin{array}{lll}\text { C1 } & \text { TO C5, } & \text { C8, } \\
\text { C9, C12, } & \text { C13, } \\
\text { C17, } & \text { C20, } & \text { C21, } \\
\text { C24, } & \text { C25, } & \text { C28, } \\
\text { C } 22\end{array}$ \\
\hline \multirow[b]{2}{*}{2} & $300 \times 900$ & $520 \times 520$ & C5 TO C28 \\
\hline & $300 \times 750$ & $474 \times 474$ & $\begin{array}{lrll}\text { C1 } & \text { TO } & \text { C4, } & \text { C29 } \\
\text { TO C32 }\end{array}$ \\
\hline \multirow[t]{2}{*}{ G,1 } & $300 \times 1100$ & $574 \times 574$ & $\begin{array}{l}\mathrm{C} 2, \mathrm{C} 3, \quad \mathrm{C} 5 \mathrm{TO} \\
\mathrm{C} 28, \mathrm{C} 30, \mathrm{C} 31\end{array}$ \\
\hline & $300 \times 750$ & $474 \times 474$ & $\mathrm{C} 1, \mathrm{C} 4, \mathrm{C} 29, \mathrm{C} 32$ \\
\hline
\end{tabular}

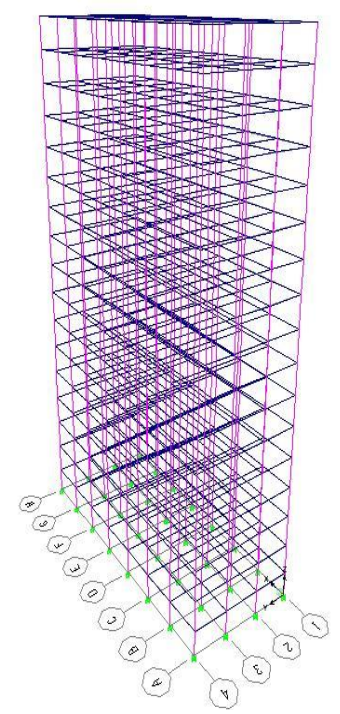

Fig 1 Typical Isometric and Plan View of G+15 Storey RC Frame

\section{Earthquake Load EQ X and EQ Y:}

This load case is static load calculated as per the Indian code IS: 1893(2002) for 5\% damping with seismic zone factor $\mathrm{Z}=0.16$ and medium soil with importance factor 1 and response reduction factor 5 . The loading direction considered as global $\mathrm{X}$ and global $\mathrm{Y}$. The mass considered for generating the lateral load is total dead load $+25 \%$ of the live load lumped at diaphragm Centre.

\section{PUSHOVER ANALYSIS CASES}

The mathematical models developed are subjected to pushover analysis as per ATC-40 provisions using ETABS software. Default plastic hinges of four types are available in the software. Out of them, P-M-M type of hinges are defined at $5 \%$ and $95 \%$ of the span for all beam and column 
elements. Moreover, flexural plastic hinges M3 are defined at mid span of beam to capture the possible development of stresses beyond yield point due to gravity loads.

There are three pushover cases specified for each model.

- $\quad$ PUSHDOWN - Push given in the gravity direction up to the full magnitude of dead load and live load starting from zero stress

- $\quad$ PUSHX - Applying lateral loads in the X direction starting from stress due to pushdown

- $\quad$ PUSHY - Applying lateral loads in the Y direction starting from stress due to pushdown

PUSH X and PUSH Y are displacement controlled in which a designated roof level node is monitored up to the initial target displacement of 0.004 times the height of the building. The other parameters are considered for pushover analyses by ETABS are P-delta effects for incorporating the geometric non linearity. These effects start governing when a few plastic hinges are fully developed and they deform the structure considerably. Apply local redistribution is used as member unloading method. The storey drift at performance point is taken as output to plot the drift parameters as an indicator of the seismic performance of a particular frame.

\section{RESULTS OF PUSHOVER ANALYSIS AT PERFORMANCE POINT}

The results of the analysis for rectangular column and equivalent square column for PUSH X and PUSH Y cases are represented in the form of deformed shapes as shown in Fig.2 and Fig.3. The corresponding demand/capacity curve of PUSH X and PUSH Y for rectangular column and square column are as shown in Fig.4 and Fig.5 respectively.

Table:-2 shows the number of hinges developed at performance point for rectangular column (R) and square column(S).

To achieve the target of keeping the building in immediate occupancy level, all IO-LS and LS-CP hinges should be eliminated. From the observation, it is said that all the hinges of IO-LS and LS-CP level are formed in beam elements. Therefore, to keep the building in immediate occupancy level, it is necessary to increase stiffness of those beams in which plastic hinges of IO-LS and LS-CP are formed. The corresponding demand/capacity curve of PUSH $\mathrm{X}$ and PUSH Y case at performance point for rectangular column and square column are as shown in Fig.6 and Fig.7. , respectively. Table:-3 shows the number of hinges developed at immediate occupancy level for rectangular column (R) and square column(S). The results of storey drift for normal building at performance point are as shown in Fig.8 and Fig.9. Here, the results of storey drift that is DRIFT X and DRIFT Y at performance point are presented as shown in Fig.10 and Fig.11, respectively.Fig.12 and Fig.13 shows the quantity of concrete and steel for both

Family of demand spectra

Single Demand Spectrum rectangular column and equivalent square column. Fig.14 shows the structural cost of all the models. The cost of concrete is considered as $4500 \mathrm{Rs} / \mathrm{cum}$ and for steel it is taken as $50 \mathrm{Rs} / \mathrm{Kg}$.

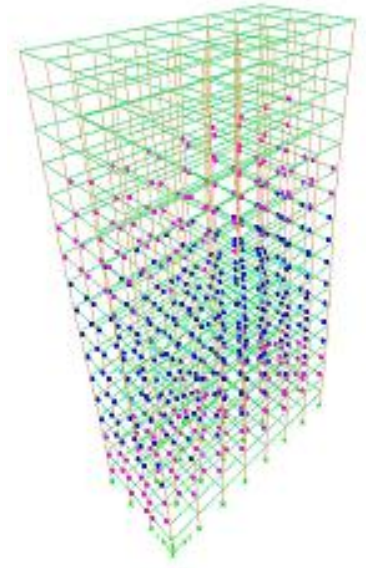

(a)Rectangular Column (b) Square Column

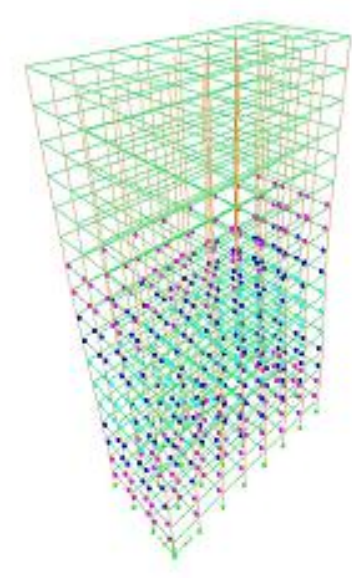

Fig.2 Deformed Shape for Rectangular and Square Column (PUSH X)

\section{上 \\ IO = Immediate Occupancy, LS = Life Safety, $\mathbf{C P}=$ Collapse Prevention}

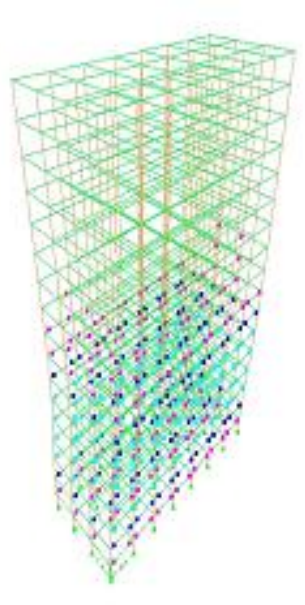

(a)Rectangular Column

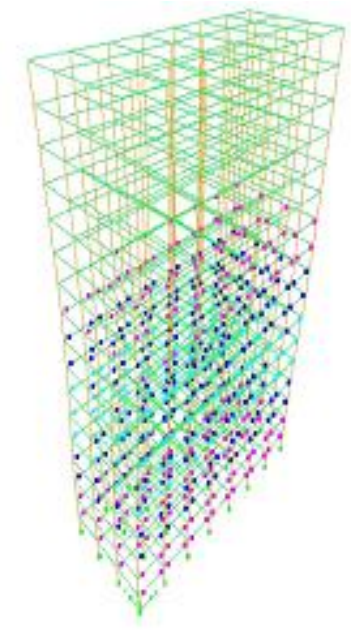

(b) Square Column
Fig.3 Deformed Shape for Rectangular and Square Column (PUSH Y)

\section{Constant period lines}




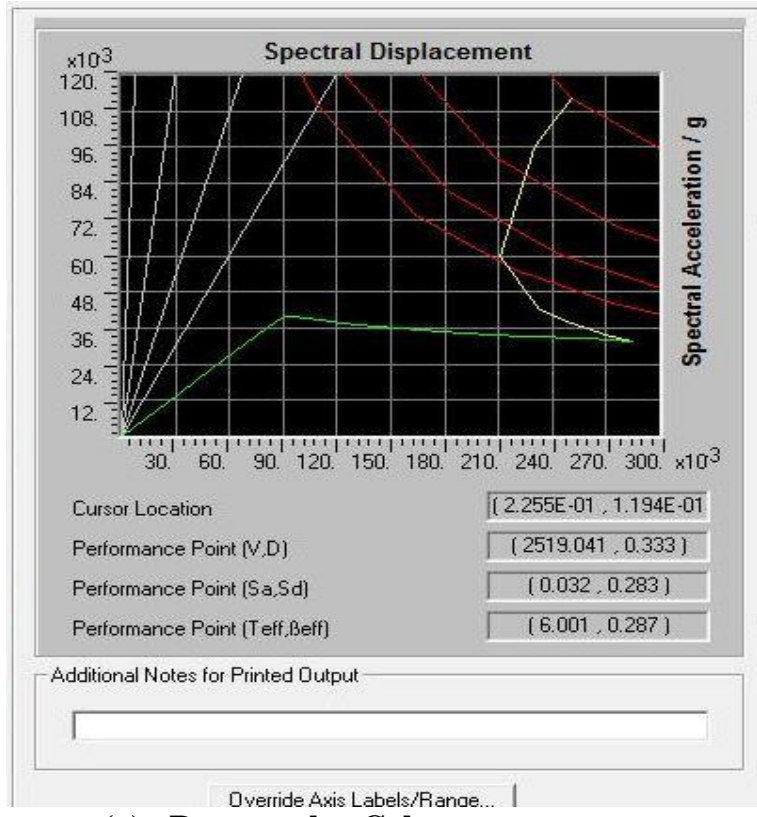

(a) Rectangular Column

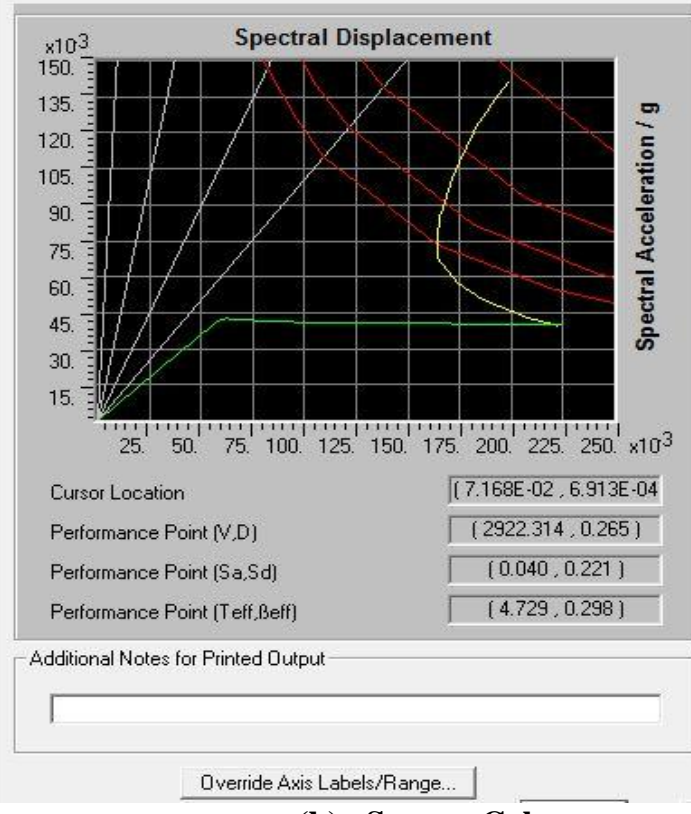

(b) Square Column

Fig.4 Demand/Capacity Curves for PUSH X

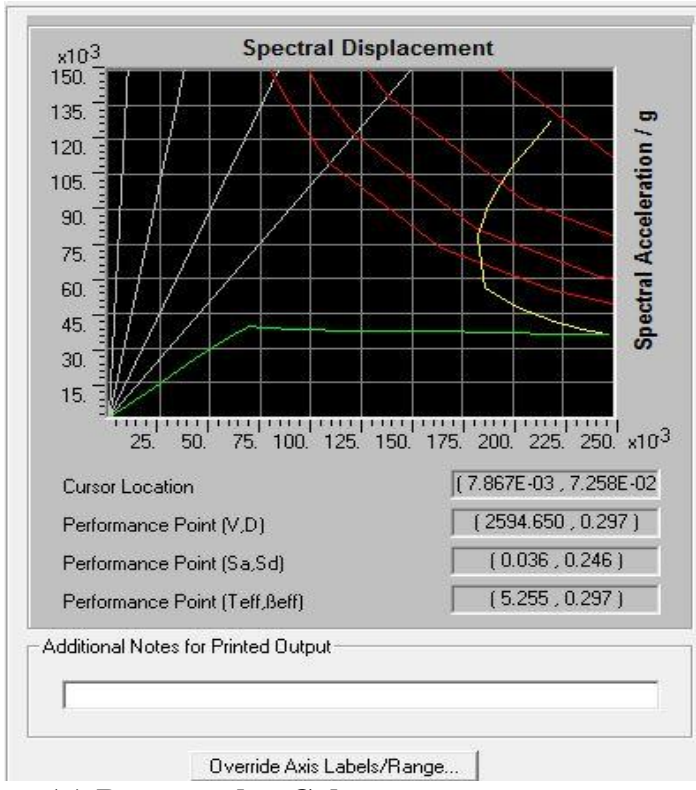

(a) Rectangular Column

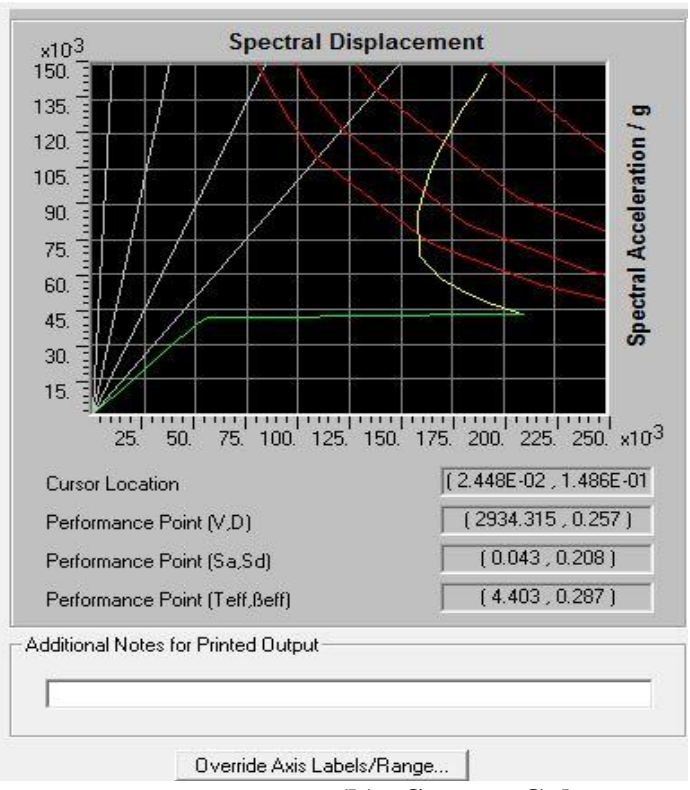

(b) Square Column

Fig.5 Demand/capacity curves for PUSH Y

Table 2:- Number of Hinges Developed Up to Performance Point for Both Models

\begin{tabular}{|c|c|c|c|c|c|c|c|c|c|c|c|c|c|c|}
\hline \multirow[t]{2}{*}{ 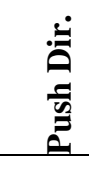 } & \multicolumn{2}{|c|}{$\begin{array}{l}\text { Roof } \\
\text { Displacement } \\
\text { (mm) }\end{array}$} & \multicolumn{2}{|c|}{ Base Force $(\mathbf{k N})$} & \multicolumn{2}{|l|}{ A-B } & \multicolumn{2}{|c|}{ B-IO } & \multicolumn{2}{|c|}{ IO-LS } & \multicolumn{2}{|c|}{ LS-CP } & \multicolumn{2}{|c|}{ TOTAL } \\
\hline & $\mathbf{R}$ & $\mathbf{S}$ & $\mathbf{R}$ & $\mathbf{S}$ & $\mathbf{R}$ & $\mathbf{S}$ & $\mathbf{R}$ & $\mathbf{S}$ & $\mathbf{R}$ & $\mathbf{S}$ & $\mathbf{R}$ & $\mathbf{S}$ & $\mathbf{R}$ & $\mathbf{S}$ \\
\hline $\mathbf{X}$ & 333 & 265 & 2519 & 2922 & 5044 & 4922 & 128 & 194 & 112 & 228 & 224 & 164 & 5508 & 5508 \\
\hline $\mathbf{Y}$ & 257 & 297 & 2934 & 2595 & 4932 & 4986 & 240 & 186 & 316 & 192 & 20 & 144 & 5508 & 5508 \\
\hline
\end{tabular}




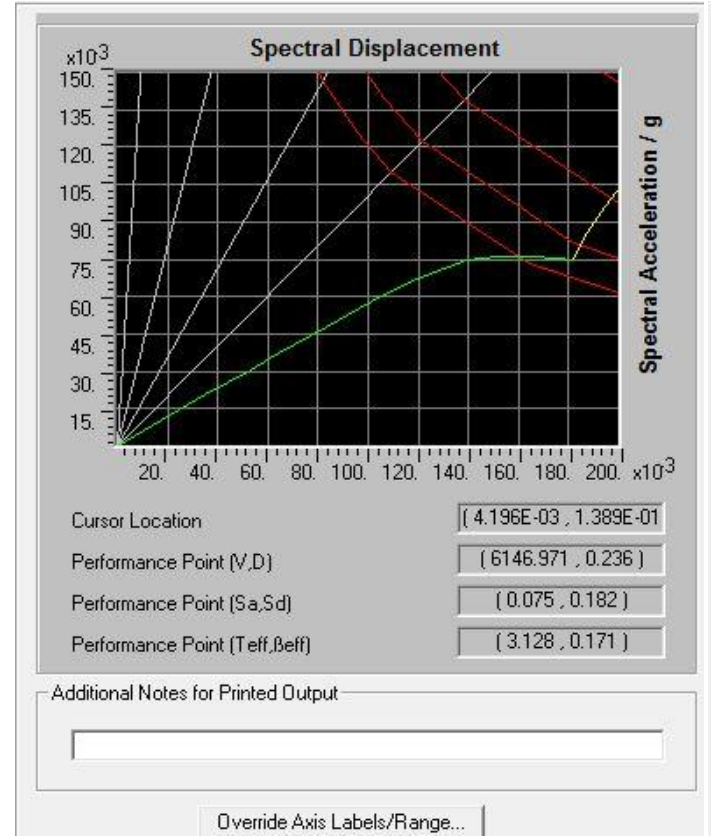

(a) Rectangular column

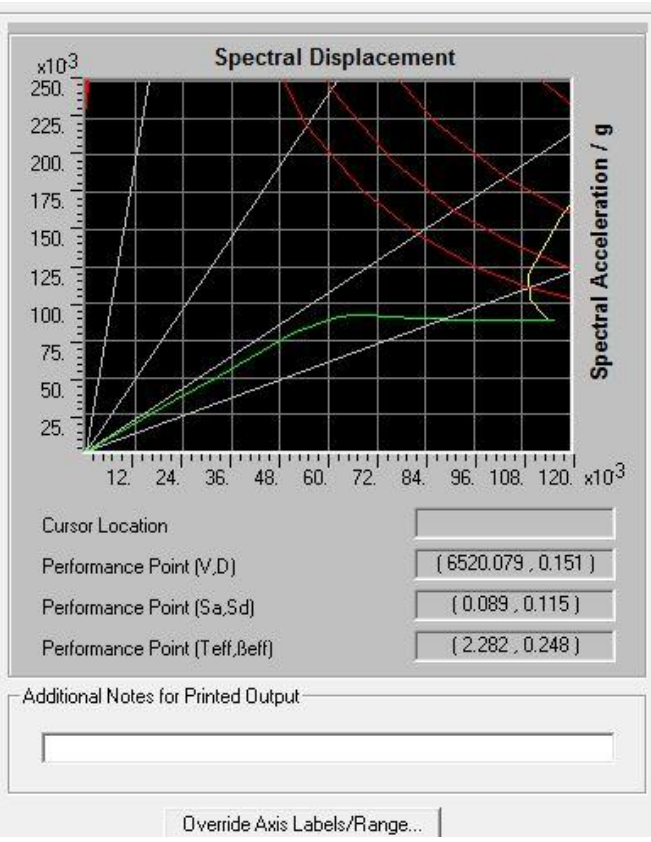

(b) Square column

Fig.6 Demand/Capacity Curves for PUSH X

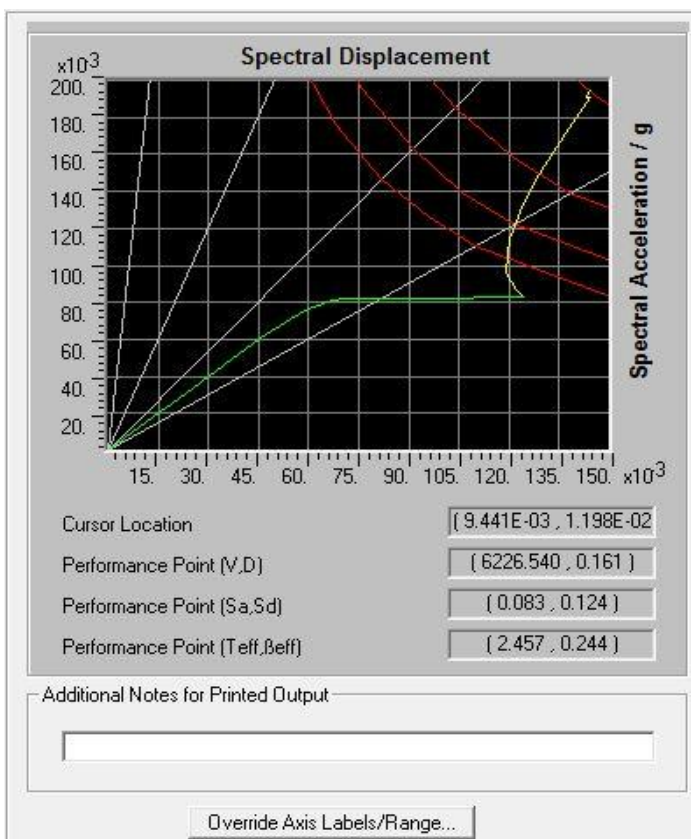

(a) Rectangular Column

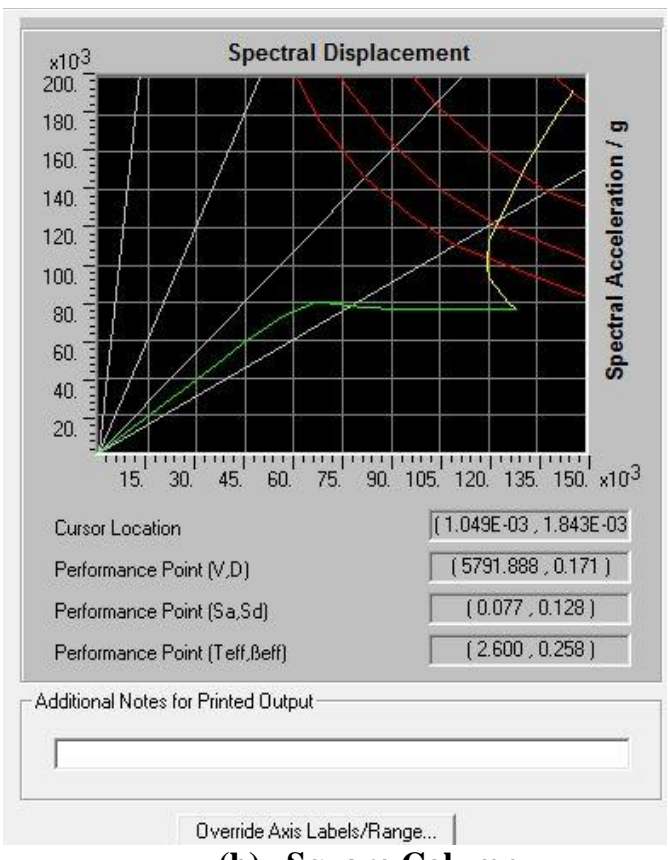

(b) Square Column

Fig.7 Demand/capacity curves for PUSH Y

Table 3:- Summary on the Parameters of Models at Performance Point

\begin{tabular}{|c|c|c|c|c|c|c|c|c|c|c|c|c|c|c|}
\hline 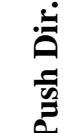 & \multicolumn{2}{|c|}{$\begin{array}{l}\text { Roof } \\
\text { Displacement } \\
(\mathbf{m m})\end{array}$} & \multicolumn{2}{|c|}{ Base Force $(\mathbf{k N})$} & \multicolumn{2}{|l|}{ A-B } & \multicolumn{2}{|c|}{ B-IO } & \multicolumn{2}{|c|}{ IO-LS } & \multicolumn{2}{|c|}{ LS-CP } & \multicolumn{2}{|c|}{ TOTAL } \\
\hline & $\mathbf{R}$ & $\mathbf{S}$ & $\mathbf{R}$ & $\mathbf{S}$ & $\mathbf{R}$ & $\mathbf{S}$ & $\mathbf{R}$ & $\mathbf{S}$ & $\mathbf{R}$ & $\mathbf{S}$ & $\mathbf{R}$ & $\mathbf{S}$ & $\mathbf{R}$ & $\mathbf{S}$ \\
\hline$X$ & 236 & 150 & 6146.971 & 6639.508 & 4946 & 4919 & 562 & 589 & 0 & 0 & 0 & 0 & 5508 & 5508 \\
\hline $\mathbf{Y}$ & 161 & 168 & 6226.54 & 5883.816 & 4980 & 4964 & 528 & 544 & 0 & 0 & 0 & 0 & 5508 & 5508 \\
\hline
\end{tabular}




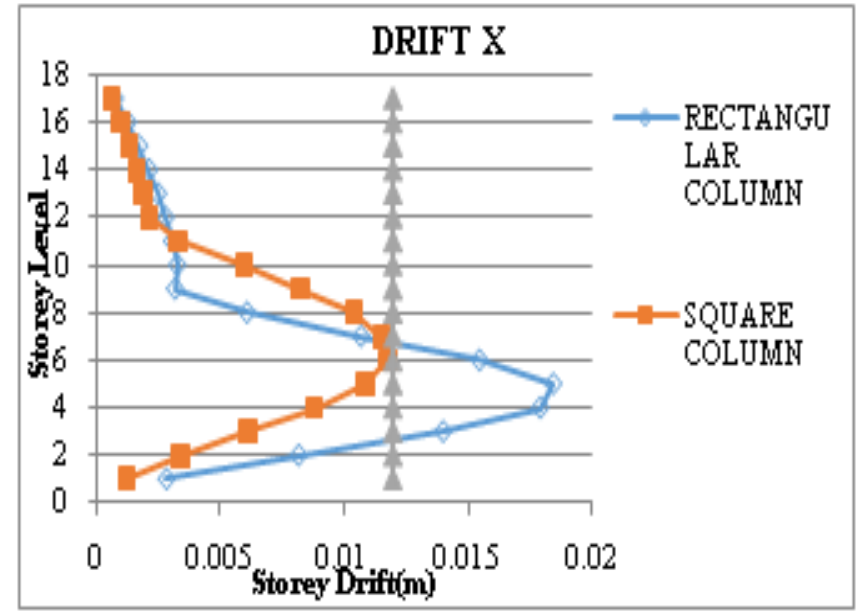

Fig.8 Storey Drift of R and S Columns in Push-X (Normal Building)

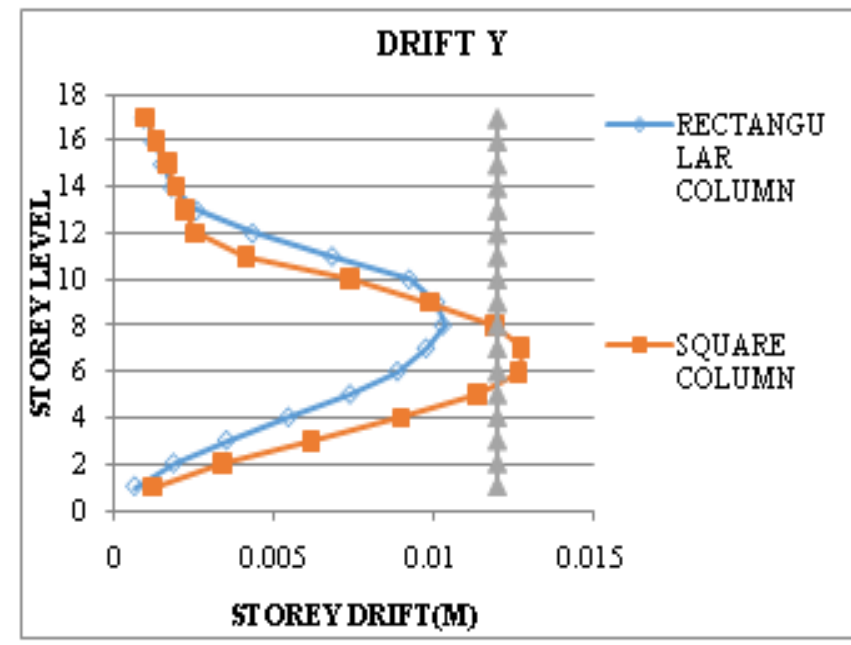

Fig.9 Storey Drift of R and S Columns in Push-Y (Normal Building)

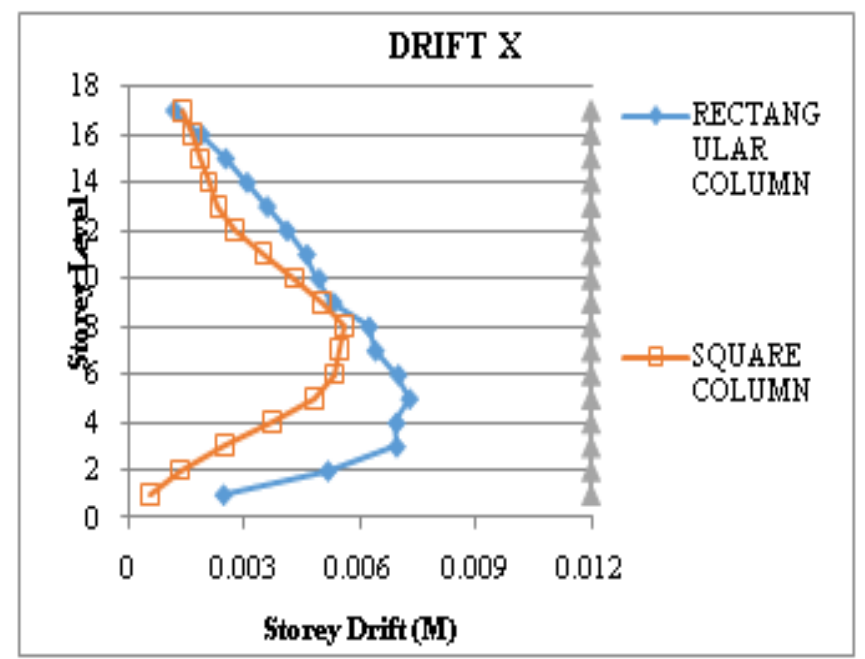

Fig.10 Storey Drift of R and S Columns in Push-X (IO Level Building)

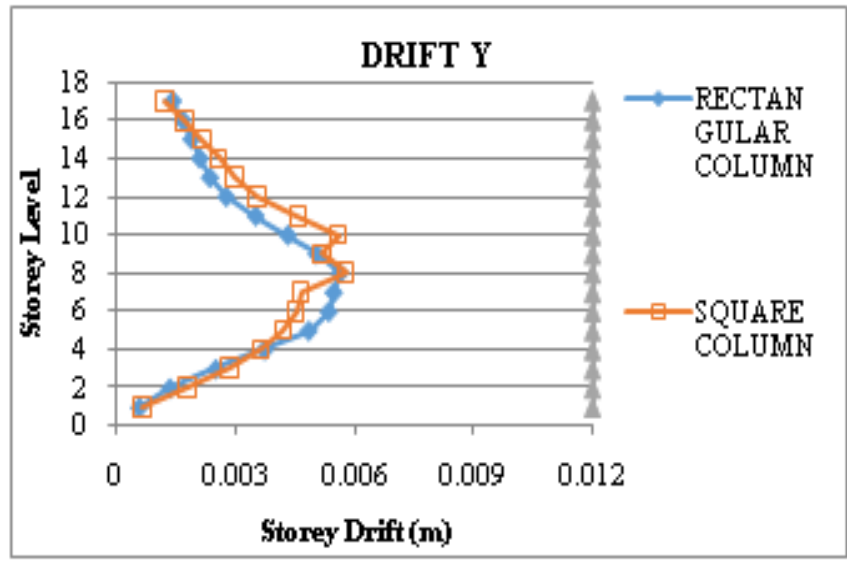

Fig.11 Storey Drift of R and S Columns in Push-Y (IO Level Building)

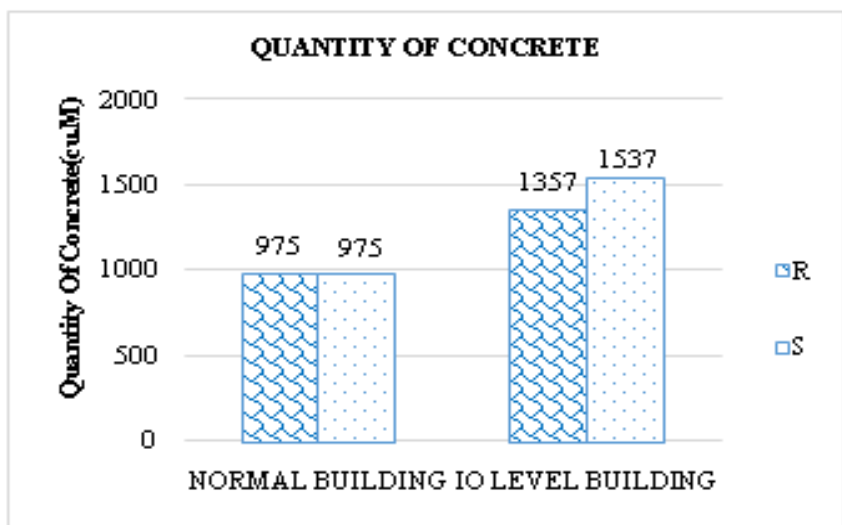

Fig.12 Quantity of Concrete in Both Models

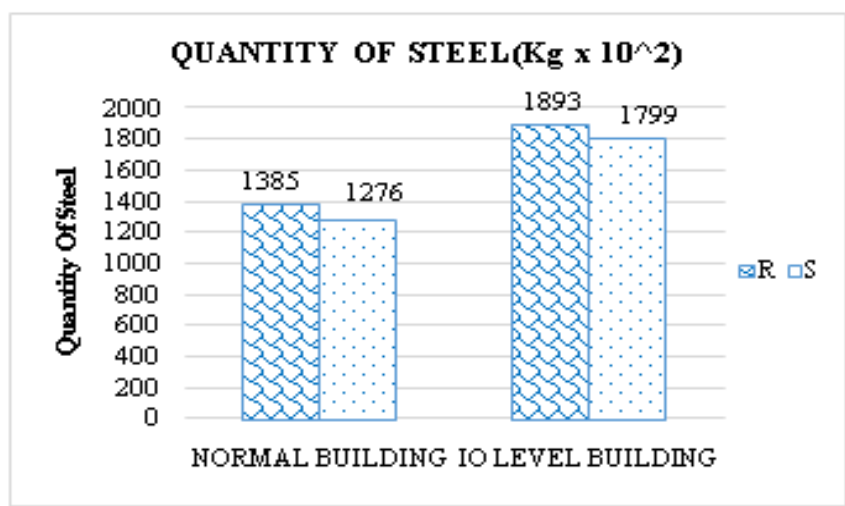

Fig.13 Quantity of Steel in Both Models

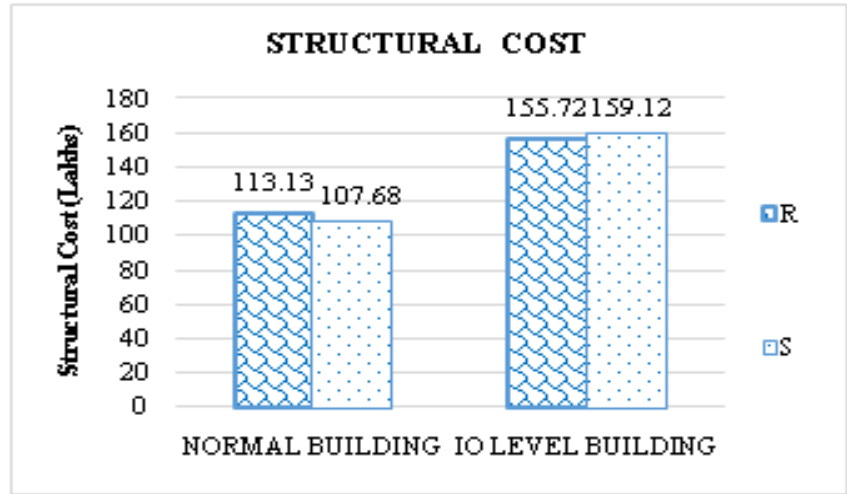

Fig.14 Structural Cost for Models 


\section{DISCUSSION OF RESULTS}

The hinges developed in rectangular column models at LS-CP level are more in numbers as compared to square columns in PUSH X case as in rectangular columns $\mathrm{X}$-direction is weak direction. This is evident from Table $\mathbf{- 1}$.

$>\quad$ The hinges developed in rectangular column models at LS-CP level are very less in numbers as compared to square columns in PUSH Y case as shown in Table-1.

$>\quad$ The deformed shape of both the models under lateral push as shown in Fig.1 and Fig.2, clearly indicates that there is more lateral deformation in the model with rectangular columns in push $\mathrm{X}$ case while in push $\mathrm{Y}$ case there is not much difference in deformed shape.

$>$ The storey drift value for normal building is increased than the permissible value of storey drift as per IS:1893 (2002) in case of push-X case for rectangular column RC frame and Push-Y case square column RC frame as shown in Fig.8 and Fig.9.

$>$ From Fig.10 it can be seen that at immediate occupancy level building, there is excessive drift in case of push $\mathrm{x}$ case in rectangular column, which indicates poor performance of rectangular column in $\mathrm{X}$ direction.

$>$ Table-2 indicates that base shear at performance point for frames with square column is more than the equivalent rectangular column when pushed in weak $\mathrm{X}$ - direction indicating superior behavior of square column.

$>$ From the Table-2 it can be noticed that in both lateral direction the roof displacement at performance point is less in case of square column model than in rectangular column model.

$>$ From Fig.10, it can be noticed that consumption of concrete at Immediate Occupancy level building compared to normal building is $\mathbf{2 8 . 1 5 \%}$ more for rectangular column and for square column it is $36.56 \%$ more.

$>\quad$ From Fig.13, it can be noticed that the consumption of steel in immediate occupancy level building when compared to normal building is $\mathbf{2 4 . 8 4 \%}$ more for rectangular column and $\mathbf{2 9 . 0 7 \%}$ more for square column model.

$>$ Also from Fig.12, it can be observed that in square column RC frame quantity of concrete used $\mathbf{1 1 . 7 1 \%}$ is more as compared to rectangular column $\mathrm{RC}$ frame at immediate occupancy level and $\mathbf{4 . 9 \%}$ more steel is utilized in rectangular column RC frame as compared to square column RC frame.

$>$ From Fig.14, it can be observed that there is not much difference in structural cost between rectangular column and square column RC frame at immediate occupancy level.

$>$ From Fig.14, it can be noticed that at immediate occupancy level the structural cost is $\mathbf{2 7 . 3 5 \%}$ more as compared to normal building in rectangular column $\mathrm{RC}$ frame while in square column $\mathrm{RC}$ frame at immediate occupancy level the structural cost is 32.33\% more as compared to normal building.

$>$ From Fig.14, it can be noticed that at immediate occupancy level, there is only $\mathbf{2 . 1 \%}$ difference in the structural cost of rectangular column RC frame and square column RC frame building.

\section{CONCLUSIONS}

We conclude from the study that

$>$ The numbers of plastic hinges developed in rectangular column $\mathrm{RC}$ frame are more as compared to square column RC frame as in rectangular column one direction is weaker direction.

$>$ Referring the result summary for RC frames, it can be seen that the number of plastic hinges developed in normal building is higher than those developed in strengthen building. Moreover, the base shear resisted at performance point is higher for the buildings which are strengthen as compare to the normal building.

$>\quad$ Storey drift are found within the limit as specified by code IS: 1893-2002, part - I in nonlinear static analysis at immediate occupancy level.

$>$ There is a little difference in structural cost of rectangular column RC frame and Square column RC frame at immediate occupancy level.

$>$ The behaviour of square column is better than rectangular column when the comparison is in terms of storey drift, base shear and roof displacement.

$>$ The performance of square column RC frame is better than the rectangular column RC frame.

\section{REFERENCES}

[1] Applied Technology Council, .Seismic Evaluation and Retrofit of Concrete Buildings., ATC-40, Volume 1 and 2, Report No. SSC 96- 01, Seismic Safety Commission, Redwood City, CA, 1996.

[2] FEMA-273, Federal Emergency Management Agency, NEHRP Guidelines and Commentary on the Guidelines for the Seismic Rehabilitation of Buildings, Washington D C, USA, 1997.

[3] IS: 1893 (Part 1): 2002, Indian Standard Criteria for Earthquake Resistant Design of Structures, Part 1: General Provisions and Buildings, Bureau of Indian Standards, New Delhi, 2002.

[4] IS 456:2000, Indian Standard Code of Practice for Plain and Reinforced Concrete, Bureau of Indian Standards, New Delhi, 2000.

[5] IS 13920:1993, Indian Standard Code of Practice for Ductile Detailing of Reinforced Structures subjected to Seismic Forces, Bureau of Indian Standards, New Delhi, 1993.

[6] "CSI Analysis Reference Manual for ETABS", Computers and Structures, Inc., Berkeley, California, USA. 


\section{BIOGRAPHIES}

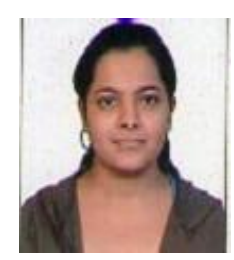

Ami A. Shah, Post Graduate Student at Applied Mechanics and Structure Engineering Department, Faculty of Technology and Engineering, The Maharaja University of Baroda, Vadodara 390001, Gujarat, India.

Dr. Bimal.A. Shah, Associate Professor, Applied Mechanics and Structure Engineering Department, Faculty of Technology and Engineering. The Maharaja University of Baroda, Vadodara 390001, Gujarat, India 